\title{
Micro-Loans In Ghana: Assessing Relationships Between Payment Of Interest And Loan Characteristics
}

\author{
Alice S. Etim, Winston Salem State University, USA \\ George Heilman, Winston Salem State University, USA \\ Peprah James, University of Cape Coast, Ghana
}

\begin{abstract}
This paper assesses differences in loan characteristic variables between those who pay interest on their micro-loans and those who don't. The findings indicate significant differences between interest payers and interest non payers based on the sufficiency of the loans, the recency of the business and loan, and the portion of profits needed to repay loans.
\end{abstract}

Keywords: Ghana; Interest Rates; Micro-Loans; Micro-Lending; Microfinance Institutions (MFIs); Sub-Saharan Africa; Unbanked; SME

\section{INTRODUCTION}

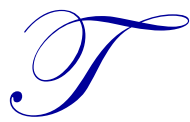

he significant need for financial sustainability by small and medium enterprises (SMEs) has made them seek borrowed funds in both the formal and informal financial sectors. However, studies show that SMEs cannot afford credit from the formal sectors that are dominated by large commercial banks because they are perceived by those lenders as high risk borrowers that lack sufficient collateral for loans (Basu et al., 2004; Etim, 2011; Padmanabhan, 1988; Targoe, Nyarko, \& Anuwa-Amarh, 2005). As a result, microfinance institutions (MFIs) have become the default lenders for SMEs and many low-income entrepreneurs.

\section{LITERATURE}

For many entrepreneurs and SMEs in the Sub-Saharan African (SSA) countries like Ghana, finding funds to support a business idea or project is an uphill task. About 80 percent of the population is unbanked (Hughes \& Lonie, 2007; Basu, 2004, Etim 2011). In Basu's 2004 study, the findings were that only about five to six percent of adults in Ghana and Tanzania had access to any form of banking services. In a recent study, it was reported that half of the world's population is unbanked (Chaia et al., 2013). This is more than 2.5 billion adults who do not use formal financial services and institutions to borrow or save funds and many of them were in SSA. In a few cases, small businesses have access to informal financial systems like the local Cooperative Societies and group lending, but those lack growth and sustainability (Armendariz \& Morduch, 2010). The influx of microfinance institutions into the SSA and countries like Ghana, Kenya, and Nigeria in the last three decades was therefore not surprising to scholars. The initial explanation was that the MFIs came to help solve the credit problem as well as provide ease of funding for development-related initiatives, particularly those that impacted entrepreneurs and SMEs. The MFIs, who themselves initially were funded by donor institutions, such as non-governmental organizations (NGOs) or development agencies, at relatively low or no fee grants now charge exorbitant interest rates for small loans. It is important to note that the funding organizations for MFI initially were not considered as formal financial institutions (Goodman, 2009). One of the most successful MFIs in SSA that owns the M-PESA mobile money, reports that the M-PESA project was initially funded with a public sector challenged grant (Hughes \& Lonie, 2007).

The outreach by MFIs has been examined in the literature. According to Lafourcade, Isern, Mangi, and Brown (2005), African MFIs are the fastest growing in the world as more than 70 percent of them are now deposittaking in various financial products like savings accounts and the regulated MFIs that are often privately owned 
posted the highest return on assets in 2005 and again in 2012. The question then is, "why is it not possible for MFIs to charge low fees and low interest rates for micro-loans?" The MFIs that are supposed to serve SMEs and entrepreneurs at a small fee are charging very high interest rates to these borrowers and such rates are often higher than those that are paid by affluent borrowers. According to Rosenberg, Gonzalez, and Narain (2009), one of the reasons for the high interest rate charges is linked to the new mission of MFIs. Many MFIs were initially nongovernmental organizations (NGOs) that provided mostly micro lending services, but they now see deposit-taking as a more lucrative, sustainable and profitable path to expansion and funding of micro-loans. The MFIs become deposit takers by approaching the governmental banking regulatory bodies, like the Bank of Ghana, for licenses for deposittaking and a host of other banking services. When such licenses are granted to MFIs, they become privately-owned commercial corporations that provide a range of services including microcredit, savings, insurance and money transfers, and their mission ultimately changes to maximizing profits for their private shareholders.

Rosenberg et al. (2009) also summarize the other reasons:

- $\quad$ administrative costs for micro lending are much higher than regular bank lending

- $\quad$ operational inefficiencies

- $\quad$ lack of financial sustainability - making MFIs and related organizations charge higher rates and fees in order to cover the cost of lending

On the issues of financial sustainability and operational inefficiencies, Rosenberg et al. (2009) explain: “...accepting the importance of financial sustainability does not end the discussion of interest rates, and where to draw the line is a complex issue. An interest rate charge represents money taken out of clients' pockets and it is unreasonable if it not only covers the costs of lending but also deposits "excessive" profits into the pockets of MFI private owners. Even an interest rate that only covers costs and includes no profit can still be unreasonable if the costs are excessively high because of avoidable inefficiencies." (p. 1)

Table 1 shows the number of MFIs in selected Africa countries. The data are organized by country, number of MFIs, active borrowers, and the gross loan portfolio in 2012. It is the result from a large study of MFIs and their borrowers by the Microfinance Information eXchange (MIX).

Table 1: Number of MFIs in Selected African Countries, Active Borrowers and Gross Loan Portfolio, 2012

\begin{tabular}{|l|c|c|c|}
\hline \multicolumn{1}{|c|}{ Country } & Number of MFIs & Active Borrowers & Gross Loan Portfolio (USD) \\
\hline Benin & 26 & 299,388 & $177,572,052$ \\
\hline Burkina Faso & 13 & 97,783 & $33,023,154$ \\
\hline Burundi & 18 & 100,893 & $30,923,939$ \\
\hline Cameroon & 8 & 116,793 & $247,734,649$ \\
\hline Chad & 2 & 14,264 & $7,991,961$ \\
\hline Congo, Democratic Republic of the & 13 & 155,757 & $127,229,259$ \\
\hline Congo, Republic of the & 2 & 5,238 & $3,586,558$ \\
\hline Cote d'Ivoire (Ivory Coast) & 12 & 36,520 & $42,096,504$ \\
\hline Ethiopia & 24 & $2,616,254$ & $558,787,567$ \\
\hline Ghana & 11 & 197,394 & $53,973,978$ \\
\hline Kenya & 23 & $1,226,743$ & $1,854,127,468$ \\
\hline Liberia & 2 & 22,488 & $3,079,348$ \\
\hline Malawi & 4 & 164,848 & $13,870,608$ \\
\hline Mali & 1 & 22,872 & $3,931,992$ \\
\hline Mozambique & 4 & 28,768 & $13,069,803$ \\
\hline Namibia & 1 & 12,684 & $3,867,860$ \\
\hline Niger & 5 & 19,301 & $7,598,000$ \\
\hline Nigeria & 12 & $1,067,808$ & $273,862,920$ \\
\hline Rwanda & 24 & 81,076 & $89,767,232$ \\
\hline Senegal & 9 & 243,888 & $222,842,331$ \\
\hline Sierra Leone & 2 & 23,585 & $2,506,023$ \\
\hline South Africa & 3 & 5,396 & $3,422,231,357$ \\
\hline Tanzania & 8 & 198,913 & $117,504,871$ \\
\hline
\end{tabular}


Table 1 cont.

\begin{tabular}{|l|c|c|c|}
\hline Togo & 9 & 108,649 & $171,369,607$ \\
\hline Uganda & 9 & 203,232 & $178,502,548$ \\
\hline Zambia & 2 & 13,807 & $2,082,659$ \\
\hline Zimbabwe & 1 & 21,401 & $19,189,087$ \\
\hline
\end{tabular}

Source of data: http://www.mixmarket.org/mfi/region/Africa

Table 1 shows that the largest number of borrowers of funds from the MFIs was from Ethiopia, Kenya, and Nigeria. For Ghana, the study reports about 11 active MFIs, with about 200,000 borrowers of funds, and the gross loan amount in U.S. dollars stood at about \$54 million. A large percentage of the SSA unbanked remains to be served effectively by MFIs. The inherent risk with the high rate loans is that some borrowers do not follow the payment terms and can default on the loans.

\section{METHODOLOGY}

A survey was created to collect a variety of information from recipients of small business micro-loans in Ghana. Students from Cape Coast University in Central Ghana administered the survey to small business owners throughout the country - Regions R1, R2, R3, and R4 (Greater Accra, Central, Eastern, and Western). The survey included questions regarding the participant and business profile, the cost of borrowed funds, participant assessment of Ghana's Entrepreneurship Program, their use of technology and record-keeping, and their expectation about the growth of their businesses.

One question asked if the respondent paid interest to their lenders. The response to this question was used to segment respondents across several attitudinal and perceptual loan-related categories in an attempt to identify relationships between loan attitude and performance information and the payment or non-payment of loan interest. All the analyses were performed using chi-square tests of independence. The null hypothesis in each test is that the Payment/Non-payment of Interest and the demographic variable being analyzed are independent. The alternative hypothesis is that the two variables are related.

A total of 398 survey responses were collected. All respondents answered the "Do you pay interest to your lender(s) - Yes/No" question. Of these, 57 respondents were paying interest on their micro-loans and 341 were not.

Some respondents, however, did not answer all the remaining questions. If a questionnaire contained a valid response to the specific demographic item being analyzed for differences, it was included in that item analysis. This means that a particular respondent may have been included in the analysis of one demographic variable but excluded in the analysis of the next demographic variable.

\section{RESULTS}

\section{By Years Since Start-Up of Business}

Table 2 shows the distribution of respondents paying interest and not paying interest by region. One interest paying respondent and five non-interesting paying respondents did not answer the question regarding the age of the business. A significant difference exists between interest payers and non-payers relative to how long ago they started their businesses (chi-square 4 d.f. $=9.97, p<.05$ ), indicating a relationship between the length of time since business start-up and payment of interest. The proportion of those paying interest on loans taken to start a business three to four years ago is significantly higher than the other business-age categories. 
Table 2: Information Regarding Years in Business

\begin{tabular}{|c|c|c|}
\hline $\begin{array}{l}\text { How long ago did you } \\
\text { start up your business }\end{array}$ & Pay Interest - Yes & Pay Interest - No \\
\hline Less than 1 year & $\begin{array}{c}5 \\
(8.9 \%) \\
\end{array}$ & $\begin{array}{c}54 \\
(16.1 \%) \\
\end{array}$ \\
\hline $1-2$ years & $\begin{array}{c}4 \\
(7.2 \%) \\
\end{array}$ & $\begin{array}{c}35 \\
(10.4 \%) \\
\end{array}$ \\
\hline $3-4$ years & $\begin{array}{c}17 \\
(30.4 \%) \\
\end{array}$ & $\begin{array}{c}49 \\
(14.6 \%) \\
\end{array}$ \\
\hline $5-8$ year & $\begin{array}{c}11 \\
(19.6 \%) \\
\end{array}$ & $\begin{array}{c}85 \\
(25.3 \%) \\
\end{array}$ \\
\hline Over 8 years & $\begin{array}{c}19 \\
(33.9 \%)\end{array}$ & $\begin{array}{c}113 \\
(33.6 \%)\end{array}$ \\
\hline Total & $\begin{array}{c}56 \\
(100 \%)\end{array}$ & $\begin{array}{c}336 \\
(100 \%)\end{array}$ \\
\hline
\end{tabular}

\section{By Percent of Profit Going to Repayment of Loans}

Table 3 shows the distribution of respondents' perceptions about the portion of their profits that are used to repay their business loans. Eight interest paying respondents and 298 non-interest paying respondents did not answer this question. A significant difference exists between interest payers and non-payers regarding their perception of how much profit is used for the repayment of their loans (chi-square 4 d.f. $=49.28, \mathrm{p}<.001$ ), indicating a relationship between perception of loan repayment burden and payment of interest. A significantly higher proportion of borrowers paying interest perceive (Agree or Strongly Agree) that 50\% or more of their profits are used for loan repayment. A t-test comparison of scoring means between interest payers and non-interest payers on loan repayment confirms the higher level of disagreement among non-interest payers (meaninterest $=3.29$, meanno-interest $=1.40$, pequal means $<.001$ ); confirming that interest payers perceived a greater portion of their profits went toward repayment of loans.

Table 3: Perception of Percent of Profit Used to Repay Loan

\begin{tabular}{|c|c|c|}
\hline $\begin{array}{l}\text { I can say that } 50 \% \text { or } \\
\text { more of my profit goes } \\
\text { to repay my loan }\end{array}$ & Pay Interest - Yes & Pay Interest - No \\
\hline Strongly Disagree & $\begin{array}{c}4 \\
(8.2 \%)\end{array}$ & $\begin{array}{c}34 \\
(79.0 \%)\end{array}$ \\
\hline Disagree & $\begin{array}{c}15 \\
(30.6 \%)\end{array}$ & $\begin{array}{c}5 \\
(11.6 \%)\end{array}$ \\
\hline No Opinion & $\begin{array}{c}7 \\
(14.3 \%)\end{array}$ & $\begin{array}{c}2 \\
(4.7 \%)\end{array}$ \\
\hline Agree & $\begin{array}{c}9 \\
(18.4 \%)\end{array}$ & $\begin{array}{c}0 \\
(0 \%)\end{array}$ \\
\hline Strongly Agree & $\begin{array}{c}14 \\
(28.5 \%)\end{array}$ & $\begin{array}{c}2 \\
(4.7 \%)\end{array}$ \\
\hline Total & $\begin{array}{c}49 \\
(100 \%)\end{array}$ & $\begin{array}{c}43 \\
(100 \%)\end{array}$ \\
\hline
\end{tabular}

\section{By Sufficiency of Loan Amount}

Table 4 shows the distribution of respondents' perceptions about the sufficiency of their small business start-up loans. Eight interest-paying respondents and 299 non-interest paying respondents did not answer this question. A significant difference exists between interest payers and non-payers regarding their perception of the start-up loan sufficiency (chi-square 4 d.f. $=39.74, \mathrm{p}<.001$ ), indicating a relationship between perception of loan sufficiency and payment of interest. A significantly higher proportion of non-interest paying borrowers perceive (Disagree or Strongly Disagree) that their loans were inadequate for their start-up needs. A t-test comparison of scoring means between interest payers and non-interest payers confirms this $\left(\right.$ mean $_{\text {interst }}=2.49$, mean $_{\text {no-interest }}=1.26$, $\left.\mathrm{p}_{\text {equal means }}<.001\right)$. 
Table 4: Loan Amount Information

\begin{tabular}{|l|c|c|}
\hline $\begin{array}{c}\text { The loan Amount that } \\
\text { I received was } \\
\text { sufficient for my small } \\
\text { business start-up }\end{array}$ & Pay Interest - Yes & Pay Interest - No \\
\hline Strongly Disagree & 10 & 36 \\
& $(20.4 \%)$ & $(85.7 \%)$ \\
\hline Disagree & 20 & 3 \\
$(40.8 \%)$ & $(7.1 \%)$ \\
\hline No Opinion & 7 & 2 \\
& $(14.3 \%)$ & 0 \\
Agree & 9 & $(0 \%)$ \\
\hline Strongly Agree & $(18.4 \%)$ & $\begin{array}{c}1 \\
(2.4 \%)\end{array}$ \\
\hline Total & 3 & 340 \\
$(6.1 \%)$ & $(100 \%)$ \\
\hline
\end{tabular}

\section{By Those Receiving a Loan Within the Last Five Year}

Table 5 shows the distribution of respondents paying interest and not paying interest by receipt of loans during the last five years. Six interest paying respondents and 37 non-interest paying respondents did not answer this question. A significant difference exists between interest payers and non-payers relative to the recency of their business (chi-square 1 d.f. $=60.52, \mathrm{p}<.001$ ) A significantly higher proportion of those paying interest have loans that are less than five years old.

Table 5: Loan Timing Information

\begin{tabular}{|l|c|c|}
\hline $\begin{array}{c}\text { I received a loan } \\
\text { during the last 5 years } \\
\text { to support my business }\end{array}$ & Pay Interest - Yes & Pay Interest - No \\
\hline Yes & 30 & 38 \\
& $(60.7 \%)$ & $(56.6 \%)$ \\
\hline \multirow{2}{*}{ No } & 21 & 266 \\
& $(21.5 \%)$ & $(32.2 \%)$ \\
\hline \multirow{2}{*}{ Total } & 54 & 304 \\
& $(100 \%)$ & $(100 \%)$ \\
\hline
\end{tabular}

\section{By Business Growth}

Table 6 shows the distribution of reported business growth for both interest-paying and noninterest-paying respondents who received business loans during the last five years. Of the 30 interest paying respondents acknowledging receipt of a loan during the last five years (see Table 4), five did not answer the question about business growth. Of the 38 non-interest paying respondents acknowledging receipt of a loan during the last five years (see Table 5), six did not answer the question about business growth.

Table 6: Annual Percentage Growth in Business if Loan Received During Last 5 Years

\begin{tabular}{|c|c|c|}
\hline $\begin{array}{c}\text { My business grows } \\
\text { about \% each year } \\
\text { since I received a loan } \\
\text { (skip in no loan in last } \\
\text { 5 years) }\end{array}$ & Pay Interest - Yes & Pay Interest - No \\
\hline $10 \%$ growth & 3 & 2 \\
\hline $15 \%$ growth & $(12.0 \%)$ & $(6.3 \%)$ \\
\hline $20 \%$ growth & 10 & 6 \\
$(40.0 \%)$ & $(18.7 \%)$ \\
\hline
\end{tabular}


Table 6 cont.

\begin{tabular}{|c|c|c|}
\hline \\
\hline $25 \%$ growth & $\begin{array}{c}5 \\
(20.0 \%) \\
\end{array}$ & $\begin{array}{c}2 \\
(6.3 \%) \\
\end{array}$ \\
\hline $30 \%$ growth & & $\begin{array}{c}2 \\
(6.3 \%) \\
\end{array}$ \\
\hline $35 \%$ growth & & $\begin{array}{c}2 \\
(6.3 \%)\end{array}$ \\
\hline $40 \%$ growth & & $\begin{array}{c}4 \\
(12.5 \%) \\
\end{array}$ \\
\hline $45 \%$ growth & & $\begin{array}{c}3 \\
(9.3 \%) \\
\end{array}$ \\
\hline $50 \%$ growth & $\begin{array}{c}2 \\
(8.0 \%)\end{array}$ & $\begin{array}{c}6 \\
(18.7 \%)\end{array}$ \\
\hline \multicolumn{3}{|l|}{$55 \%$ growth } \\
\hline $60 \%$ growth & $\begin{array}{c}2 \\
(8.0 \%) \\
\end{array}$ & $\begin{array}{c}1 \\
(3.0 \%) \\
\end{array}$ \\
\hline \multicolumn{3}{|l|}{$65 \%$ growth } \\
\hline $70 \%$ growth & & $\begin{array}{c}2 \\
(6.3 \%) \\
\end{array}$ \\
\hline \multicolumn{3}{|l|}{$75 \%$ growth } \\
\hline $80 \%$ growth & $\begin{array}{c}2 \\
(8.0 \%) \\
\end{array}$ & \\
\hline Total & $\begin{array}{c}25 \\
(100 \%)\end{array}$ & $\begin{array}{c}32 \\
(100 \%)\end{array}$ \\
\hline
\end{tabular}

Even though the respondents were asked to estimate business growth in an open-ended format, all provided answers that were some multiple of 5\%. Because of the wide range of responses and the presence of so many empty cells, the responses were grouped into two categories - estimated growth rate less than $25 \%$ and estimated growth rate of $25 \%$ or higher. See Table 7 for category summaries.

Table 7: Categorized Percentage Growth in Business if Loan Received During Last 5 Years

\begin{tabular}{|l|c|c|}
\hline $\begin{array}{c}\text { My business grows about \% each year } \\
\text { since I received a loan (skip in no loan in last } \\
\text { 5 years) }\end{array}$ & Pay Interest - Yes & Pay Interest - No \\
\hline Less than 25\% annual growth & 14 & 10 \\
& $(56.0 \%)$ & $(31.3 \%)$ \\
\hline \multirow{2}{*}{ 25\% or higher annual growth } & 11 & 22 \\
Total & $(44.0 \%)$ & 32 \\
\hline
\end{tabular}

A chi-squared test on the data presented in Table 7 shows marginal significance (chi-square 1 d.f. $=3.53, p$ $=.06$ ), indicating a possible relationship between the payment of interest and the perceptions of business growth among those respondents who have received loans during the last five years.

\section{CONCLUSION}

In conclusion, the study helps to show that a higher proportion of those not paying interest perceived that they had a greater rate of annual business growth than those paying interest (Table 7). It helps to support the position that is established in the literature that borrowers who pay interest regularly felt burdened by high interest rates. A significant difference also existed between interest payers and non-payers regarding their perception of the start-up loan sufficiency. A significantly higher proportion of non-interest paying borrowers did perceive (Disagree or Strongly Disagree) that their loans were inadequate for their start-up needs and therefore failed to pay interest on the loans.

Finally, this paper helps to establish a position that the interest rate required on a micro-loan can significantly impact the ability of a SME borrower to repay the loan as well as the associated interest charges, particularly since up to 50 percent of a borrower's profit margin can be used to service such a micro-loan. 


\section{AUTHOR INFORMATION}

Alice S. Etim earned her Ph.D. at the University of North Carolina at Chapel Hill. She researches information and communication technology (ICT) adoption by business organizations, project teams and the Bottom of the Pyramid (BOP) populations as well as the applications of such technologies in business, commerce, microfinance and healthcare. Dr. Etim is currently Assistant Professor of Management Information Systems at Winston Salem State University. She is a certified Project Management Professional (PMP®) and had worked for IBM Software Group for 12 years in various positions, including Staff Software Engineer and Project Manager. E-mail: etima@wssu.edu (Corresponding author)

George E. Heilman earned his Ph.D. at the University of Arkansas. He is currently a Professor of Management Information Systems at Winston-Salem State University.

Peprah James is a Senior Lecturer in Economics at the Department of Economics, University of Cape Coast, Ghana. He holds a Ph.D. in Economics, MPhil in Economics and Bilingual MBA (Banking and Finance). His areas of research include development economics, financial market and institution in developing countries, microfinance, growth and development, as well as small scale enterprise studies. James has a number of publications that focus on SMEs, microfinance, and poverty in Ghana. His current research focuses on global comparison of MFI performance, entrepreneurial ability among tertiary students, failure of MFIs, regulation and public policy of MFIs, and addiction to MFIs in Ghana.

\section{REFERENCES}

1. Armendariz, B., \& Morduch, J. (2010). The economics of microfinance. Cambridge, MA: MIT Press, $2^{\text {nd }}$ edition.

2. Basu, A., Blavy, R., \& Yulek, M. (2004). Microfinance in Africa: Experience and lessons from selected African countries. (IMF Working Paper, WP/04/174).

3. Chaia, A., Dalal, A., Goland, T., Gonzalez, M., Morduch, J., \& Schiff, R. (2013). Half the world is unbanked. In R. Cull, A. Demirguc-Kunt, \& J. Morduch (ed.), Banking the world: Empirical foundations of financial inclusion. Cambridge, MA: MIT Press.

4. Etim, A. S. (2011). Bottom-up business development: Empowering low income societies through microfinance and mobile technologies. International Journal of Humanities and Social Science, 1(13).

5. Goodman, P. (2009). Raising MFI equity through microfinance investment funds. In J. D. Pischke \& I. Matthaus-Maier (ed.), New partnership for innovation in microfinance (pp. 17-45). Berlin Heidelberg: Springer.

6. Hughes, N., \& Lonie, S. (2007). M-PESA: Mobile money for the "Unbanked", turning cellphones into 24hour tellers in Kenya. Innovations, winter \& spring.

7. Lafourcade, A., Isern, J., Mangi, P., \& Brown, M. (2005). Overview of the outreach and financial performance of microfinance institutions in Africa. Symposium on Microfinance Investment Funds, Berlin, Germany.

8. Padmanabhan, K. P. (1988). Rural credit: Lessons for rural bankers and policy makers. London, U.K.: Intermediate Technology Publications.

9. Rosenberg, R., Gonzalez, A., \& Narain, S. (2009). The new moneylenders: Are the poor being exploited by high microcredit interest rates? The Consultative Group to Assist the Poor (CGAP), 15, Retrieved December 5, 2013, from http://econ336-s12-basole.wikispaces.umb.edu/file/view/ Microfinance_Interest_Rates.pdf

10. Tagoe, N., Nyarko, E., \& Anuwa-Amarh, E. (2005). Financial challenges facing urban SMEs under Financial Sector Liberalization in Ghana). Journal of Small Business Management, 43(3), 331-343. 
NOTES 